\title{
Green Bio-Based CaO from Guinea Fowl Eggshells
}

\author{
Mary-Magdalene Pedavoah',2*, Mercy Badu², Nathaniel O. Boadi², Johannes A. M. Awudza² \\ ${ }^{1}$ Department of Applied Chemistry and Biochemistry, Faculty of Applied Sciences, University for Development Studies, \\ Navrongo, Ghana \\ ${ }^{2}$ Department of Chemistry, College of Science, Kwame Nkrumah University of Science and Technology, Kumasi, Ghana \\ Email: *mmpeddy@yahoo.com
}

How to cite this paper: Pedavoah, M.-M., Badu, M., Boadi, N.O. and Awudza, J.A.M. (2018) Green Bio-Based $\mathrm{CaO}$ from Guinea Fowl Eggshells. Green and Sustainable Chemistry, 8, 208-219.

https://doi.org/10.4236/gsc.2018.82015

Received: March 21, 2018

Accepted: May 28, 2018

Published: May 31, 2018

Copyright $\odot 2018$ by authors and Scientific Research Publishing Inc. This work is licensed under the Creative Commons Attribution International License (CC BY 4.0).

http://creativecommons.org/licenses/by/4.0/

\begin{abstract}
Eggshells are among the emerging hazardous waste from the food processing industry. This work sought to valorize waste guinea fowl eggshells. Guinea fowl eggshells (GFEs) were evaluated in the production of $\mathrm{CaO}$ for chemical and industrial application. The functionality, thermal stability, elemental composition, phase distribution and surface morphology properties of uncalcined GFEs and GFEs calcined at $700^{\circ} \mathrm{C}, 800^{\circ} \mathrm{C}, 900^{\circ} \mathrm{C}, 1000^{\circ} \mathrm{C}$ and $1100^{\circ} \mathrm{C}$ were systematically studied by FTIR, TGA, XRF, XRD and SEM-EDX respectively. The elemental analysis revealed $\mathrm{Ca}$ as the main element in the GFEs. The uncalcined GFEs showed intense peaks that corresponded to calcite $\left(\mathrm{CaCO}_{3}\right)$ phases. These transformed into $\mathrm{Ca}(\mathrm{OH})_{2}$ as the temperature of calcination increased and finally to $\mathrm{CaO}$ in the FTIR analysis. In the XRD diffractograms, the main peaks at $2 \theta$ values were $29.466^{\circ}$ for the uncalcined GFESs and at $37.377^{\circ}$ for the sample treated at $1100^{\circ} \mathrm{C}$. The phases were confirmed as $\mathrm{CaO}$ when compared with JCPDS files. Using the Scherer equation, the $\mathrm{CaO}$ crystallite size for the sample calcined at $1100^{\circ} \mathrm{C}$ was found to be $50.68 \mathrm{~nm}$ along the (2 00$)$ orientation. All the samples showed multi-step decomposition patterns in the thermogravimetric analyses (TGA), with weight loss of up to $47 \%$ for the uncalcined GFEs sample, which was mainly due to the transformation of the calcite $\left(\mathrm{CaCO}_{3}\right)$ phase to $\mathrm{CaO}$ by removal of bound water, organic components, and $\mathrm{CO}_{2}$. Samples calcined at $1100^{\circ} \mathrm{C}$ showed mainly $\mathrm{CaO}$ phases in XRD analyses and fairly stable with $7 \%$ loss in weight after treatment at $800^{\circ} \mathrm{C}$. SEM images of samples calcined at $900^{\circ} \mathrm{C}$ were irregular compared to samples treated at $1100^{\circ} \mathrm{C}$. EDX data revealed that the surface structure was $100 \%$ calcium and oxygen. GFEs are a potential source of pure calcium oxide for various industrial uses.
\end{abstract}

\section{Keywords}

Sustainable Materials, CaO, Biowaste, TGA, SEM-EDX, XRD 


\section{Introduction}

To guarantee sustainable development, there is the need to consider valorization of waste to ensure zero waste standards. Again, in the wake of "green chemistry" there is the need to develop new sustainable materials that are reusable, recyclable and green [1]. In this context there is a growing interest in the use of naturally occurring and bio-based compounds as industrial feedstock.

There has therefore been a shift in attention in research into developing new clean technology and more environmentally friendly compounds to substitute the use of harmful reagents and catalysts in the chemical industry [2]. In a review published recently by Laca et al., [3], egg processing waste was listed among the emerging problems in the food industry and considered as hazardous waste by UE regulations. However, waste eggshells have opportunities for the bioeconomy if new uses are ascribed to these materials. Waste eggshells are some of the useful agricultural bio-wastes that fall directly under the category of materials that are biodegradable, recyclable, and biocompatible, with a good osteoconductivity [4]. Annually, millions of tonnes of various eggshells go waste across the world, especially from the food processing industries [5]. In Brazil, 12,000 tonnes of avian eggshell waste are generated annually [6] and 15,000 tonnes in Canada annually. [5] These materials which generate $\mathrm{H}_{2} \mathrm{~S}$ with associated offensive smell are usually disposed in open disposal sites or landfills.

The functional characteristics of eggshells are currently the object of intense research [7] [8]. The avian eggshell is about $11 \%$ of the egg weight [9] [10] and contains about $93 \%-96 \% \mathrm{CaCO}_{3}$ [9] [11]. Eggshells [12] [13] and other shells from various animals, including oysters [14], mud crab [15] snails, molluscs [16] and ducks have been successfully converted into $\mathrm{CaO}$. These have been used in the development of value added products [17], such as non-conventional heterogeneous catalysts for biodiesel production [18] [19] [20] as a strengthening agent in ceramic materials [6] and for the synthesis of hydroxyapatite used as scaffolds in biomedical applications [21] [22]. CaO from some eggshells have been successfully used as green, rapid and efficient catalysts in biodiesel production and other organic synthesis [23] [24] [25]. As indicated by Eletta et al., [26] eggshell- $\mathrm{CaO}$ has been used as an adsorbent for metals in waste water treatment with negligible environmental impacts and high reusability. There is however, no report on the production, characterization and use of $\mathrm{CaO}$ from guinea fowl eggshells. The helmeted guinea fowl (Numida meleagris) accounts for almost 98\% of birds kept by farmers in Northern, Upper East and Upper West Regions of Ghana and over 7\% of the total poultry production in Ghana. With about 70\% of the vegetation ideal for its production [27] [28], there are currently various interventions aiming at expanding production for food security and poverty reduction. Although there have been numerous studies on the socio-economics for guinea fowl production none has considered the potential uses of the waste eggshells associated with production.

This study explored for the first time the synthesis and characterization of 
guinea fowl eggshells (GFEs) as an alternative source of $\mathrm{CaO}$. The focus of the work was to thoroughly characterize and compare the functional and chemical properties of untreated GFEs, synthesized $\mathrm{CaO}$ (from the calcined GFEs) and commercially acquired $\mathrm{CaO}$ using Fourier Transform infra-red spectroscopy (FT IR), thermogravimetric analysis (TGA), X-ray diffraction (XRD), Scanning Electron Microscopy (SEM), and energy dispersive X-ray fluorescence spectroscopy (EDXRF).

\section{Experimental}

\subsection{Materials}

Commercial $\mathrm{CaCO}_{3}$ and $\mathrm{CaO}$ (95\%) of analytical grade were purchased from $\mathrm{BDH}$, Labo Chemie (Mumbai, India). Waste guinea fowl eggs shells were collected from domestic waste, over a period of four weeks from the Sunbrungu area in the Upper East Region of Ghana.

\subsection{Sample Preparation and Calcination of GFESs}

The eggshells were washed with running water and rinsed in warm water to reduce organic materials. The sample was oven dried at $105^{\circ} \mathrm{C}$ for 2 hours and crushed in a stainless steel grinder. The GFEs were calcined by heating at elevated temperatures in the range of $700^{\circ} \mathrm{C}-1100^{\circ} \mathrm{C}$ with 2 hours hold time. The calcined samples were stored in capped glass vials to avoid reaction with air and moisture.

\subsection{Instrumental Methods for Characterization of Guinea Fowl Egg Shells (GFESs)-CaO}

The functional groups of GFEs and calcined samples were identified by Fourier transform infrared (FTIR) analyses using a Perkin Elmer spectrum II (94133) in ATR mode, with NIOS2 at a resolution of 4 and 24 scans, at $400-4000 \mathrm{~cm}^{-1}$ and with a resolution of $1 \mathrm{~cm}^{-1}$. Background spectra were obtained before sampling. The crystalline phases and qualitative composition of the samples were studied by X-ray diffraction (XRD) using an X-ray tube with $\mathrm{Cu} \mathrm{k} \alpha$ radiation $(\Lambda=$ 1.5412) source accelerated at $40 \mathrm{~mA}$ and $40 \mathrm{kV}$ and a graphite secondary beam monochromator. The radiation was in the range of $10-802 \theta$ angle. The intensity was measured by continuous scanning with a step size of 0.033 and measuring time of $100 \mathrm{~s}$. The phases were identified by comparing with Joint Committee on Powder Diffraction Standard (JCPDS) files. The thermal stability and weight loss of the uncalcined and calcined samples were evaluated by thermo-gravimetric analyses (TGA) (Mettler Toledo) in a temperature range of $30^{\circ} \mathrm{C}-1000^{\circ} \mathrm{C}$ at a heating rate of $10^{\circ} \mathrm{C} \mathrm{min}^{-1}$ under nitrogen atmosphere and the samples held at $1000^{\circ} \mathrm{C}$ for 10 minutes. Elemental composition analysis was investigated by using a hand held XRF instrument. Scanning electron microscopy (SEM) images were taken at 2000x and 10000x magnification. EDX was used to characterize the elemental composition of the surface structure of the GFESs 
samples. The loss in ignition of the GFEs samples was determined by calculation using the relationship: $\operatorname{Loi}=\left(A_{i}-A_{f}\right) / A_{i} \times 100$; where $A_{i}$ is the weight of the sample before calcination and $A_{f}$ is the weight of the sample after calcination. Colour change analysis of samples was by visual inspection.

\section{Results and Discussion}

\subsection{Effect of Calcination on GFEs}

The calcination process was accompanied by a series of colour changes, from light brown to grey and then white as the temperature increased from $700^{\circ} \mathrm{C}$ to $1100^{\circ} \mathrm{C}$. The grey colour transformation observed at both $700^{\circ} \mathrm{C}$ and $800^{\circ} \mathrm{C}$ was due to the combustion of egg membranes and other organic components reducing the sample to mainly calcite $\left(\mathrm{CaCO}_{3}\right)$. Formation of Lime $(\mathrm{CaO})$, a white crystalline material produced from the decomposition of $\mathrm{CaCO}_{3}$ at elevated temperatures was confirmed above $800^{\circ} \mathrm{C}$ with the formation of white samples. These transformations during calcination accounted for the corresponding weight loss in the samples (Table 1).

\subsection{Thermal Stability and Decomposition Pattern of GFES-CaO Studied by Thermogravimetric Analysis}

Thermal decomposition of GFES-CaO was investigated by TGA (Figure 1). The thermograms of samples depict a multi-step decomposition. Minor weight losses were observed between $0^{\circ} \mathrm{C}-300^{\circ} \mathrm{C}$ which may be due to removal of moisture and organic components, with major loss occurring between $300^{\circ} \mathrm{C}$ and $800^{\circ} \mathrm{C}$ (decomposition of $\mathrm{CaCO}_{3}$ ). TGA revealed weight loss of about $47 \%$ in the uncalcined GFESs mainly due to the decomposition of $\mathrm{CaCO}_{3}$ and formation of $\mathrm{CaO}$ and $\mathrm{CO}_{2}$. This weight loss was similar to those observed for samples calcined above $800^{\circ} \mathrm{C}$ in Table 1 . The sample treated up to $1100^{\circ} \mathrm{C}$ was fairly stable after a temperature of $450^{\circ} \mathrm{C}$ with about $7 \%$ loss in weight. No weight loss was observed after about $850^{\circ} \mathrm{C}$ for the uncalcined GFESs in TGA, which implies that complete transformation had occurred at this temperature; thus optimum. Previous studies by Singh and Sharma [29] indicated that when calcination temperature is

Table 1. GFESs weight loss at varying temperature treatments with corresponding colour changes (in muffle furnace).

\begin{tabular}{ccc}
\hline Temperature treatment $\left({ }^{\circ} \mathrm{C}\right)$ & Loi $(\%)$ & Colour of sample \\
\hline 105 (Uncalcined GFESs) & $0.98 \pm 0.05$ & LB \\
700 & $12.93 \pm 0.67$ & DG \\
800 & $46.58 \pm 0.15$ & LG \\
900 & $47.65 \pm 0.01$ & W \\
1000 & $47.73 \pm 0.19$ & W \\
1100 & $48.48 \pm 0.24$ & W \\
\hline
\end{tabular}

Loi-weight loss on ignition, LB-light brown, DG—dark grey, LG—light grey, W—white. 


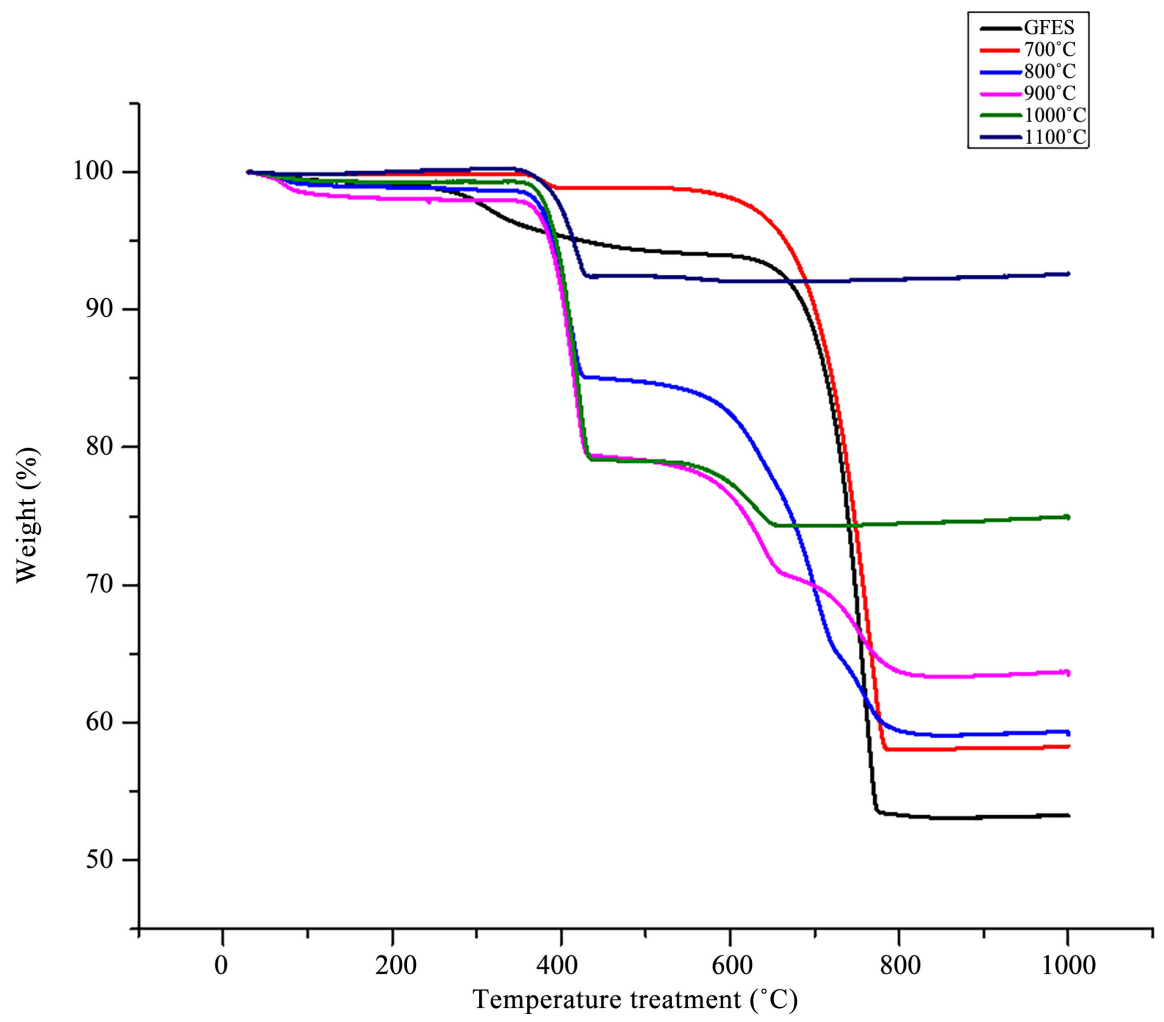

Figure 1. TGA analysis of uncalcined and calcined GFESs.

beyond $1000^{\circ} \mathrm{C}$ it increases sintering effect. This phenomenon reduces the catalytic activity of $\mathrm{CaO}$ due to reduced surface area. This could have accounted for the slight increase in masses observed in the TGA analysis of the samples after $900^{\circ} \mathrm{C}$. Optimum temperature for calcination of was chosen above $800^{\circ} \mathrm{C}$ in earlier works reported by Birla et al., [30] and Mosaddegh and Hassankhani [24]. Again, in a study by Viriya-empikul et al., [13] [16] a temperature of $800^{\circ} \mathrm{C}$ was selected as the suitable temperature for the calcination of waste mollusks shells to obtain $\mathrm{CaO}$; Wei et al., [12] used temperatures above $800^{\circ} \mathrm{C}$ to produce $\mathrm{CaO}$ from eggshells while Nakatani et al:; [14] it also reported $700^{\circ} \mathrm{C}$ and above for the transformation of oyster shells to $\mathrm{CaO}$.

\subsection{Phase Transformation of Calcined GFEs by X-Ray Diffraction (XRD) Analysis}

$\mathrm{XRD}$ patterns gave information on the crystalline phases in the samples. The XRD patterns of the calcined and untreated GFEs are presented in Figure 2. The untreated sample and sample treated at $700^{\circ} \mathrm{C}$ temperature showed similar peaks which are characteristic of crystalline phases of $\mathrm{CaCO}_{3}$ and corresponds to Ca$\mathrm{CO}_{3}$ phases as reported by Jazie et al. [31] and Tangboriboon et al. [32]. This data indicated that a temperature of $700^{\circ} \mathrm{C}$ and hold time of 2 hours in the furnace was not sufficient to decompose $\mathrm{CaCO}_{3}$. The samples calcined at $800^{\circ} \mathrm{C}, 900^{\circ} \mathrm{C}$ and $1000^{\circ} \mathrm{C}$ for hold time of 2 hours also had similar peak patterns corresponding mainly to $\mathrm{Ca}(\mathrm{OH})_{2}$ phases mixed with some $\mathrm{CaCO}_{3}$ phases. This can be attributed 


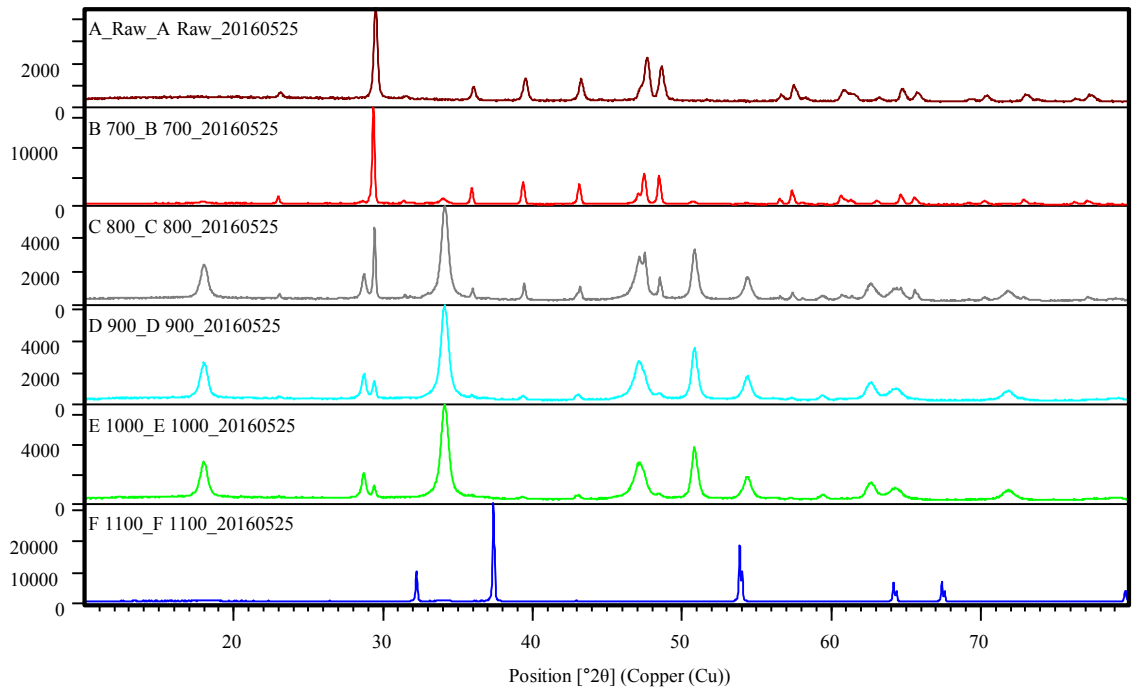

Figure 2. Stacked plot of XRD spectra of raw and calcined GFESs, (treated in the temperature range of $700^{\circ} \mathrm{C}, 800^{\circ} \mathrm{C}, 900^{\circ} \mathrm{C}, 1000^{\circ} \mathrm{C}$ and $1100^{\circ} \mathrm{C}$ respectively).

to phase transformation of calcite to lime. However, lime could have absorbed atmospheric moisture resulting in the formation of $\mathrm{Ca}(\mathrm{OH})_{2}$. The major peaks associated with $\mathrm{CaCO}_{3}$ reduced in intensity at elevated temperatures from $800^{\circ} \mathrm{C}$ to $1000^{\circ} \mathrm{C}$. At $1100^{\circ} \mathrm{C}$ calcite peaks were absent; sharp peaks of $\mathrm{CaO}$ phases were visible at $2 \theta$ values of $32.23^{\circ} \mathrm{C}, 37.37^{\circ} \mathrm{C}, 53.87^{\circ} \mathrm{C}, 64.37^{\circ} \mathrm{C}$ and $67.60^{\circ} \mathrm{C}$, which corresponded to the (111), (200), (220), (311) and (222) planes. In previous studies by Cree and Rutter [5] formation of $\mathrm{CaO}$ started at about $500^{\circ} \mathrm{C}$. However, concentrations below $1 \%$ are not detectable in XRD due to detection limits of the equipment but became visible when concentration was amplified at higher temperature. The fore mentioned could be a probable explanation for the absence of $\mathrm{CaO}$ phases in the XRD patterns for samples below $1100^{\circ} \mathrm{C}$. The crystallite size of the $\mathrm{CaO}$ produced at $1100^{\circ} \mathrm{C}$ was calculated using the Scherer equation. The GFEs produced $\mathrm{CaO}$ with average crystallite size of $50.68 \mathrm{~nm}$, along the $\left(\begin{array}{lll}2 & 0 & 0\end{array}\right)$ plane.

\subsection{FT-IR Analysis of GFE-CaO}

Fourier transform spectra were used to confirm the functional groups present in the GFE-CaO (Figure 3). The uncalcined GFEs exhibited medium absorption peak at frequency band of $1415 \mathrm{~cm}^{-1}$, one broad band at $1082 \mathrm{~cm}^{-1}$ and two sharp peaks at 873 and $712 \mathrm{~cm}^{-1}$. These peaks are associated with vibration bands for carbonate $\mathrm{CO}_{3}^{2-}$ ions. The sharp peaks observed at about $3641 \mathrm{~cm}^{-1}$ in the FT-IR spectra are characteristic of $-\mathrm{OH}$ groups of $\mathrm{Ca}(\mathrm{OH})_{2}$ formed from absorption of water by $\mathrm{CaO}$. This absorption band was observed in all the calcined samples. The intensities of the characteristic peaks related to $\mathrm{CaCO}_{3}$ at $1406 \mathrm{~cm}^{-1}$ and $1052 \mathrm{~cm}^{-1}$ decreased as calcination temperature increased, since peak size is linked with concentration of the compound. It implied that the amount of $\mathrm{CaCO}_{3}$ reduced as it transformed into $\mathrm{CaO}$. Engin et al. [33] detected 


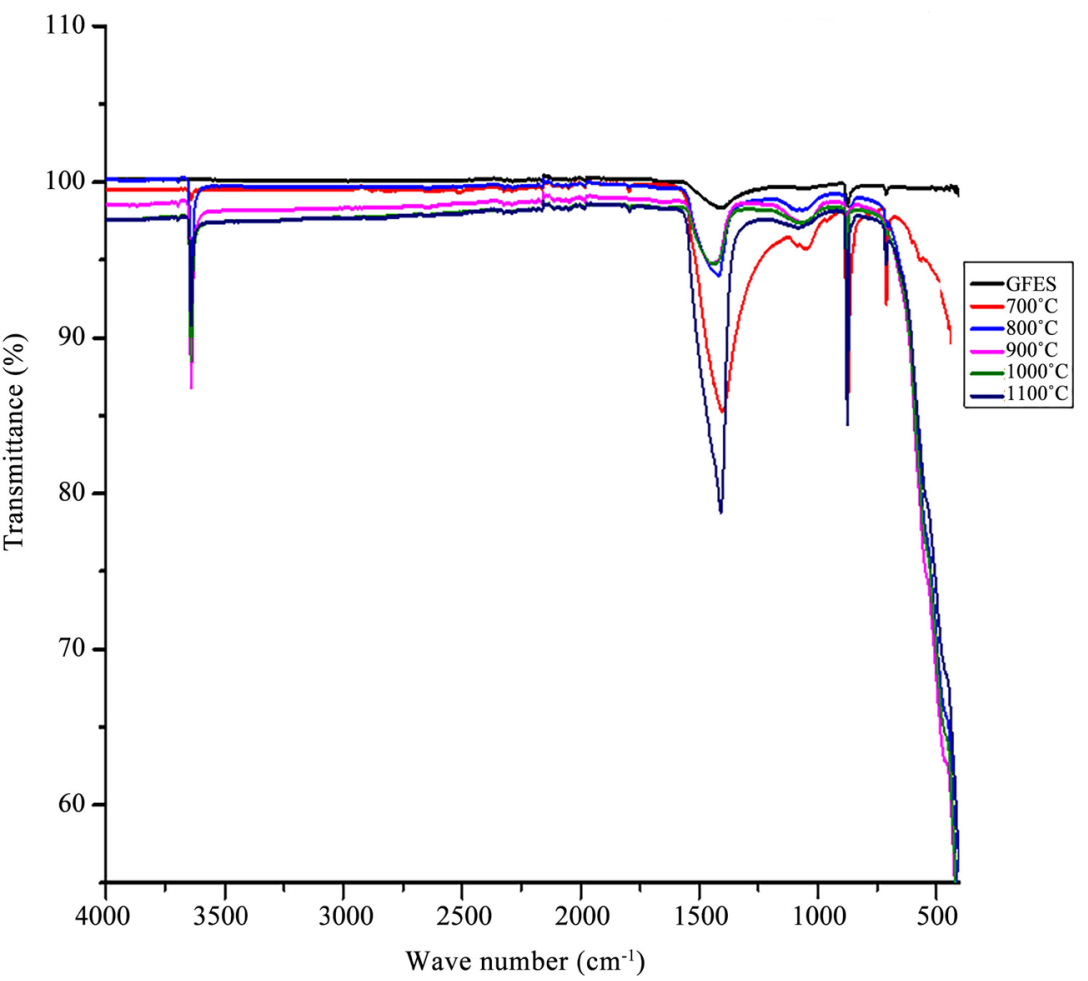

Figure 3. FTIR of uncalcined GFEs and calcined GFEs (treated in the temperature range of $700^{\circ} \mathrm{C}, 800^{\circ} \mathrm{C}, 900^{\circ} \mathrm{C}, 1000^{\circ} \mathrm{C}$ and $1100^{\circ} \mathrm{C}$ respectively).

that less intense peaks of $-\mathrm{C}-\mathrm{O}$ groups were observed as temperature increased. Also similar trends were reported in previous studies by Cree and Rutter [5], and Jazie et al., [31] who attributed the shift in absorption bands to higher energy to the reduction in $\mathrm{CaCO}_{3}$ during decomposition.

\subsection{Elemental Composition of GFES-CaO by XRF Analysis}

The elemental composition of the samples was determined by XRF data in Table 2. Calcium was identified as the major element is the samples, with about $47.91 \% \mathrm{Ca}$ in the uncalcined GFEs and this increased to about $61.86 \%$ after the removal of organic materials at $700^{\circ} \mathrm{C}$. Moradi et al. [34] found about $50.85 \% \mathrm{Ca}$ in XRF analysis of calcined mussel shells. Commercial $\mathrm{CaO}$ and $\mathrm{CaCO}_{3}$ in this study had lower amounts of calcium compared with the calcined GFEs in Table 2. The GFEs samples also contained trace amounts of $\mathrm{Ba}, \mathrm{Fe}, \mathrm{K}, \mathrm{S}$ and Sr. However, $\mathrm{Ba}, \mathrm{K}$ and $\mathrm{S}$ concentrations were below detectable limits in commercial $\mathrm{CaO}$ sample. Oxides of elements like $\mathrm{Ba}$ and $\mathrm{Sr}$ have been used to enhance the catalytic activity of $\mathrm{CaO}$ in literature. However, the levels recorded in this study are negligible compared to $\mathrm{Ca}$ and may not have impact on the $\mathrm{CaO}$ produced.

\subsection{Surface Morphology and Elemental Composition of GFEs CaO Studied by SEM and EDX}

The morphology of the GFE-CaO particles was observed by Scanning Electron Microscopy (SEM). 
The images showed irregular clusters of spherical particles for both samples calcined at $900^{\circ} \mathrm{C}$ and $1100^{\circ} \mathrm{C}$ at high magnification (10,000x) (Figure $4(\mathrm{a})$ and Figure 4(b)) and low magnification (2000x) ((Figure 4(c) and Figure 4(d)) respectively. The resulting spectra from the inspection fields of the energy dispersive X-ray spectroscopy (EDX) (Figure 5(a) and Figure 5(b)) suggest that the calcined samples were mainly calcium and oxygen as indicated in Table 3. According to Viriya-empikul et al., [13] the surface area and calcium oxide content of eggshells are the key parameters that specifically affect the catalytic activity. This implies that the GFE-CaO will have high catalytic activity since the surface composition is mainly calcium and oxygen.

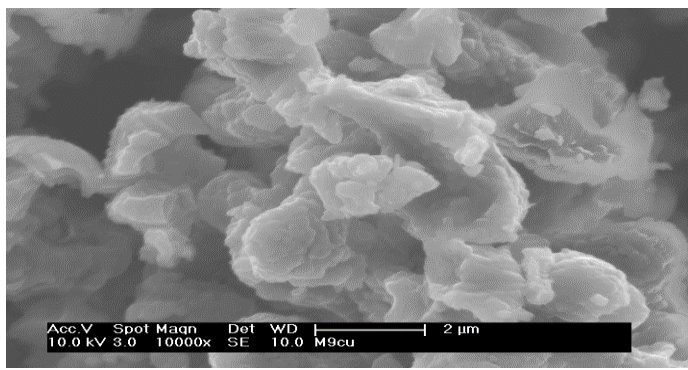

(a)

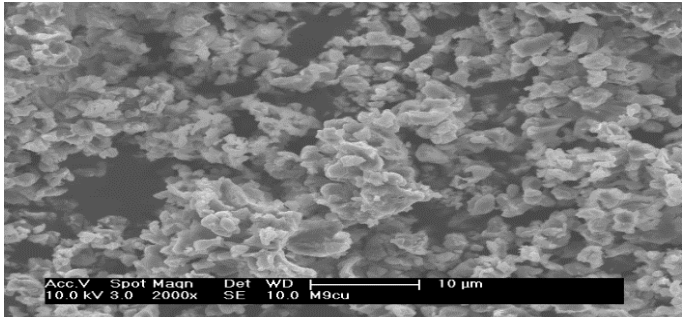

(c)

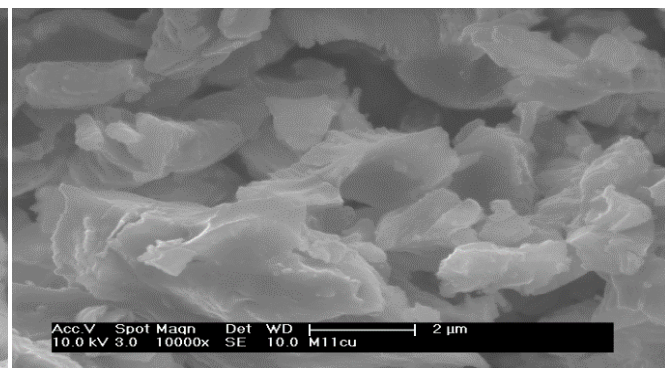

(b)

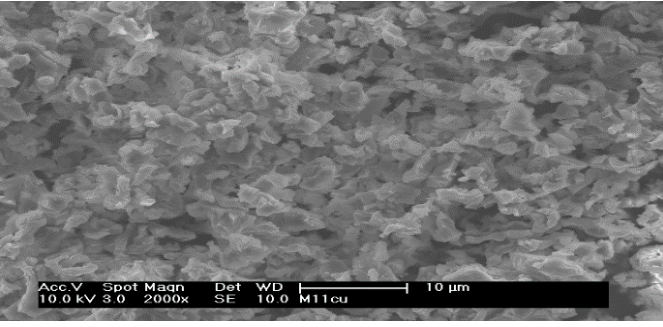

(d)

Figure 4. SEM and EDX of GFEs samples calcined at $900^{\circ} \mathrm{C}$ and $1100^{\circ} \mathrm{C}$. (a) SEM of sample treated at $900^{\circ} \mathrm{C}$ (magnification of $10,000 \times, 2 \mu \mathrm{m}$ ); (b) SEM of sample treated at $1100^{\circ} \mathrm{C}$ (magnification of $10,000 \times$, $2 \mu \mathrm{m}$ ); (c) SEM of sample treated at $900^{\circ} \mathrm{C}$ (magnification of $2000 \times, 10 \mu \mathrm{m}$ ); (d) SEM of sample treated at $1100^{\circ} \mathrm{C}$ (magnification of $\left.2000 \times, 10 \mu \mathrm{m}\right)$.

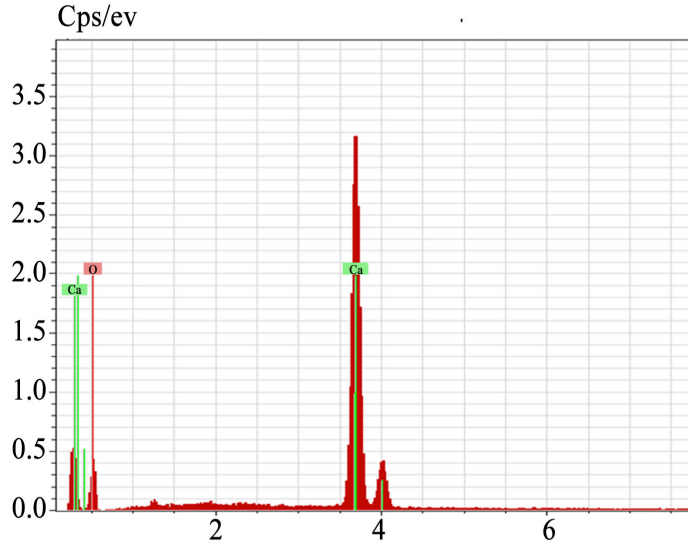

(a)

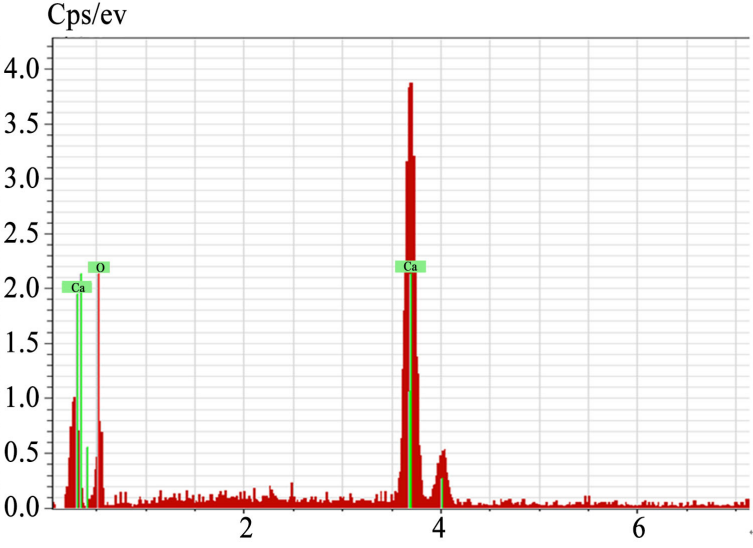

(b)

Figure 5. (a) EDX of sample treated at $900^{\circ} \mathrm{C}$; (b) EDX of sample treated at $1100^{\circ} \mathrm{C}$. 
Table 2. Elemental composition of uncalcined and calcined GFESs form XRF analyses.

\begin{tabular}{ccccccc}
\hline SAMPLE & $\begin{array}{c}\mathrm{Ba} \\
(\% \mathrm{w} / \mathrm{w})\end{array}$ & $\begin{array}{c}\mathrm{Ca} \\
(\% \mathrm{w} / \mathrm{w})\end{array}$ & $\begin{array}{c}\mathrm{Fe} \\
(\% \mathrm{w} / \mathrm{w})\end{array}$ & $\begin{array}{c}\mathrm{K} \\
(\% \mathrm{w} / \mathrm{w})\end{array}$ & $\begin{array}{c}\mathrm{S} \\
(\% \mathrm{w} / \mathrm{w})\end{array}$ & $\begin{array}{c}\mathrm{Sr} \\
(\% \mathrm{w} / \mathrm{w})\end{array}$ \\
\hline $\begin{array}{c}\mathrm{Commercial} \\
\mathrm{CaO}\end{array}$ & $<\mathrm{LOD}$ & $60.35 \pm 0.38$ & $0.07 \pm 0.04$ & $<\mathrm{LOD}$ & $<\mathrm{LOD}$ & $0.02 \pm 0.00$ \\
$\mathrm{UGFEs}$ & $0.10 \pm 0.00$ & $47.91 \pm 1.91$ & $0.04 \pm 0.01$ & $0.18 \pm 0.01$ & $0.76 \pm 0.03$ & $0.13 \pm 0.01$ \\
$\mathbf{7 0 0}{ }^{\circ} \mathrm{C}$ & $0.12 \pm 0.01$ & $61.86 \pm 1.32$ & $0.05 \pm 0.01$ & $0.10 \pm 0.01$ & $0.15 \pm 0.01$ & $0.21 \pm 0.00$ \\
$\mathbf{8 0 0} \mathrm{C}$ & $0.19 \pm 0.01$ & $70.83 \pm 1.86$ & $0.05 \pm 0.02$ & $0.11 \pm 0.02$ & $0.15 \pm 0.02$ & $0.32 \pm 0.02$ \\
$\mathbf{9 0 0}{ }^{\circ} \mathrm{C}$ & $0.19 \pm 0.02$ & $71.04 \pm 0.96$ & $0.06 \pm 0.02$ & $0.08 \pm 0.02$ & $0.15 \pm 0.03$ & $0.31 \pm 0.01$ \\
$\mathbf{1 0 0 0}{ }^{\circ} \mathrm{C}$ & $0.19 \pm 0.00$ & $73.70 \pm 0.73$ & $0.04 \pm 0.02$ & $0.06 \pm 0.02$ & $0.14 \pm 0.05$ & $0.34 \pm 0.01$ \\
$\mathbf{1 1 0 0}{ }^{\circ} \mathrm{C}$ & $0.20 \pm 0.00$ & $71.65 \pm 0.67$ & $0.06 \pm 0.03$ & $0.06 \pm 0.03$ & $0.16 \pm 0.02$ & $0.34 \pm 0.01$ \\
$\mathrm{Commercial}^{\circ}$ & $<\mathrm{LOD}$ & $55.48 \pm 0.96$ & $0.07 \pm 0.04$ & $0.04 \pm 0.00$ & $0.15 \pm 0.02$ & $0.03 \pm 0.00$ \\
$\mathrm{CaCO}_{3}$ & & & & & & \\
\hline
\end{tabular}

UGFEs: unclaimed guinea fowl egg shells, LOD: lower than detectable concentration.

Table 3. Surface composition of GFE-Cao synthesized at $900^{\circ} \mathrm{C}$ and $1100^{\circ} \mathrm{C}$ by EDX.

\begin{tabular}{rcc}
\hline Sample & Element & Weight (\%) \\
$900{ }^{\circ} \mathrm{C}$ & calcium & 55.50 \\
$900^{\circ} \mathrm{C}$ & oxygen & 44.50 \\
Total & & 100 \\
$1100^{\circ} \mathrm{C}$ & calcium & 58.64 \\
$1100^{\circ} \mathrm{C}$ & oxygen & 41.36 \\
Total & & 100 \\
\hline
\end{tabular}

\section{Conclusion}

In this study, the most suitable temperature for the conversion of waste guinea fowl eggshells (GFEs) to calcium oxide $(\mathrm{CaO})$ was investigated. The characterization techniques employed confirmed that GFEs were mainly calcite. Both FTIR and XRF data indicated the presence of $\mathrm{CaO}$ in all the calcined GFE samples. However, $\mathrm{CaO}$ crystallite phases were more prominent in the XRD analysis of the sample calcined at $1100^{\circ} \mathrm{C}$. SEM showed bulky particles, which were more regular in the sample calcined at $1100^{\circ} \mathrm{C}$. EDX data also confirmed the surface elemental composition of the calcined GFE samples at $900^{\circ} \mathrm{C}$ and $1100^{\circ} \mathrm{C}$ to be $100 \%$ calcium and oxygen. Therefore, at temperatures above $900^{\circ} \mathrm{C}$ and a hold time of 2 hours GFEs were successfully converted to pure $\mathrm{CaO}$. The results suggest that GFEs are promising sources of pure bio-based $\mathrm{CaCO}_{3}$ for $\mathrm{CaO}$ production with potential chemical and industrial applications.

\section{Acknowledgements}

M-M. Pedavoah is grateful for the support of Michael B. Mensah, Selina A. Saah and the Schools of Materials and Chemistry, University of Manchester for the assistance during the characterization of the synthesized $\mathrm{CaO}$. 


\section{References}

[1] Garcia-Serna, J., Perez-Barrigon, L. and Cocero, M.J. (2007) New Trends for Design towards Sustainability in Chemical Engineering: Green Engineering. Chemical Engineering Journal, 133, 7-30. https://doi.org/10.1016/j.cej.2007.02.028

[2] Potdar, M.K., Kelso, G.F., Schwarz, L., Zhang, C. and Hearn, M. T.W. (2015) Recent Developments in Chemical Synthesis with Biocatalysts in Ionic Liquids. Molecules, 20, 16788-16816. https://doi.org/10.3390/molecules200916788

[3] Laca, A., Laca, A. and Daiz, M. (2017) Eggshell Waste as Catalyst: A Review. Journal of Environmental Management, 197, 351-359. https://doi.org/10.1016/j.jenvman.2017.03.088

[4] Neunzehn, J., Szuwart, T. and Wiesmann, H. (2015) Eggshells as Natural Calcium Carbonate Source in Combination with Hyaluronan as Beneficial Additives for Bone Graft Materials, an in Vitro Study. Head \& Face Medicine, 11, 12. https://doi.org/10.1186/s13005-015-0070-0

[5] Cree, D. and Rutter, A. (2015) Sustainable Bio-Inspired Limestone Eggshell Powder for Potential Industrialized Applications. Sustainable Chemistry \& Engineering, 3, 941-949.

[6] Freire, M.N. and Holanda, J.N.F. (2006) Characterization of Avian Eggshell Waste Aiming Its Use in a Ceramic Wall Tile Paste. Ceramics, 52, 240-244. https://doi.org/10.1590/S0366-69132006000400004

[7] Laca, A., Paredes, B., Rendueles, M. and Diaz. M. (2014) Egg Yolk Granules, Separation, Characteristics and Applications in Food Industry. LWT-Food Science and Technology, 59, 1-5.

[8] Laca, A., Paredes, B., Rendueles M. and Diaz, M. (2015) Egg Yolk Plasma, Separation, Characteristics and Future Prospects. LWT-Food Science and Technology, 62, 7-10. https://doi.org/10.1016/j.lwt.2015.01.048

[9] Khandelwal, H. and Prakash, S. (2016) Synthesis and Characterization of Hydroxyapatite Powder by Eggshell. Journal of Minerals and Materials Characterization and Engineering, 4, 119-126. https://doi.org/10.4236/jmmce.2016.42011

[10] Wu, S., Tsou, H., Hsu, H., Hsu, S., Liou, S. and Ho, W. (2013) A Hydrothermal Synthesis of Eggshell and Fruit Waste Extract to Produce Nanosized Hydroxyapatite. Ceramics International, 39, 8183-8188. https://doi.org/10.1016/j.ceramint.2013.03.094

[11] Oliveira, D.A., Benelli, P. and Amante, E.R. (2013) A Literature Review on Adding Value to Solid Residues: Egg Shells. Journal of Cleaner Production, 46, 42-47. https://doi.org/10.1016/j.jclepro.2012.09.045

[12] Wei, Z., Xu, C. and Li, B. (2009) Application of Waste Eggshells as Low-Cost Solid Catalyst for Biodiesel Production. Bioresource Technology, 100, 2883-2885. https://doi.org/10.1016/j.biortech.2008.12.039

[13] Viriya-empikul, N., Krasae, P., Puttasawat, B., Yoosuk, B., Chollacoop, N. and Faungnawakij, K. (2010) Waste Shells of Mollusk and Egg as Biodiesel Production Catalysts. Bioresource Technology, 101, 3765-3767. https://doi.org/10.1016/j.biortech.2009.12.079

[14] Nakatani, N., Takamori, J., Takeda, K. and Sakugawa, H. (2009) Transesterification of Soybean Oil Using Combusted Oyster Shell Waste as a Catalyst. Bioresource Technology, 100, 1510-1513. https://doi.org/10.1016/j.biortech.2008.09.007

[15] Boey, P.L., Maniam, G.P. and Hamid, S.A. (2011) Performance of Calcium Oxide as a Heterogenous Catalyt in Biodiesel Production: A Review. Chemical Engineering 
Journal, 168, 15-22. https://doi.org/10.1016/j.cej.2011.01.009

[16] Viriya-empikul, N., Krasae, P., Nualpaeng, W., Yoosuk, B. and Faungnawakij, K. (2012) Biodiesel Production over Ca-Based Solid Catalyst Derived from Industrial Waste. Fuel, 92, 239-244. https://doi.org/10.1016/j.fuel.2011.07.013

[17] Gao, Y. and Xu, C. (2012) Synthesis of Dimethyl Carbonate over Waste Eggshell Catalyst. Catalysis Today, 190, 107-111. https://doi.org/10.1016/j.cattod.2011.12.004

[18] Mardhiah, H.H., Ong, H.C., Masjuki, H.H., Lim, S. and Lee, H.V. (2017) A Review on Latest Developments and Future Prospects of Heterogeneous Catalyst in Biodiesel Production from Non-Edible Oils. Renewable and Sustainable Energy Reviews, 67, 1225-1136. https://doi.org/10.1016/j.rser.2016.09.036

[19] Niju, S., Begum, K.M.M.S. and Anantharaman, N. (2015) Preparation of Biodiesel from Waste Frying Oil Using a Green and Renewable Solid Catalyst Derived from Egg Shell. Environmental Progress \& Sustainable Energy, 34, 248-254. https://doi.org/10.1002/ep.11939

[20] Omotoso, M.A. and Akinsanoye, O.A. (2015) A Review of Biodiesel Generation from Non-Edible Seed Oils Crop Using Non-Conventional Heterogeneous Catalysts. Journal of Petroleum Technology and Alternative Fuels, 6, 1-12. https://doi.org/10.5897/JPTAF2014.0108

[21] Abdulrahman, I., Tijani, H.I., Mohammed, B.A., Saidu, H., Yusuf, H., Jibrin, M.N. and Mohammed, S. (2014) From Garbage to Biomaterials: An Overview on Egg Shell Based Hydroxyapatite. Journal of Materials, 2014, Article ID: 802467. https://doi.org/10.1155/2014/802467

[22] Ramesh, S., Natasha, A.N., Tan, C.Y., Bang, L.T., Ching, C.Y. and Chandran, H. (2016) Direct Conversion of Eggshell to Hydroxyapatite Ceramic by a Sintering Method. Ceramics International, 42, 7824-7829. https://doi.org/10.1016/j.ceramint.2016.02.015

[23] Liu, X., He, H., Wang, Y., Zhu, S. and Piao, X. (2008) Transesterification of Soybean Oil to Biodiesel Using $\mathrm{CaO}$ as a Solid Base Catalyst. Fuel, 87, 216-221. https://doi.org/10.1016/j.fuel.2007.04.013

[24] Mosaddegh, E. and Hassankhani, A. (2014) Preparation of Nano-CaO Based on eggshell Waste: Novel Green Catalytic Approach to Highly Efficient Synthesis of Pyrano[4, 3-b]Pyrans. Chinese Journal of Catalysis, 35, 351-356. https://doi.org/10.1016/S1872-2067(12)60755-4

[25] Zabeti, M., Daud, W.M.A.W. and Aroua, M.K. (2009) Activity of Solid Catalysts for Biodiesel Production: A Review. Applied Catalysis A: General, 366, 154-159.

[26] Eletta, O.A.A., Ajayi, O.A., Ogunleye, O.O. and Akpan, I.C. (2016) Adsorption of Cyanide from Aqueous Solution Using Calcinated Eggshells: Equilibrium and Optimisation Studies. Journal of Environmental Chemical Engineering, 4, 1367-1375. https://doi.org/10.1016/j.jece.2016.01.020

[27] Avornyo, F.K., Salifu, S., Panyan, E.K., Al-Hassan, B.I., Ahiagbe, M. and Yeboah, F. (2016) Chracteristics of Guinea Fowl Production Systems in Northern Ghana. A Baseline Study of 20 Districts in Northern Ghana. Livestock Research for Rural Development, 28. http://www.lrrd.org/lrrd28/8/avor28134.html

[28] FAO (2014) Poultry Sector Ghana. FAO Animal Production and Health Livestock Country Reviews, No. 6, Rome. http://www.fao.org/docrep/019/i3663e/i3663e.pdf

[29] Singh, V. and Sharma, Y.C. (2017) Low Cost Guinea Fowl Bone Derived Recyclable Heterogeneous Catalyst for Microwave Assisted Transesterification of Annona squamosal L. Seed Oil. Energy Conversion and Management, 138, 627-637. https://doi.org/10.1016/j.enconman.2017.02.037 
[30] Buasri, A., Chaiyut, N., Loryuenyong, V., Wongweang, C. and Khamsrisuk S. (2013) Application of Eggshell Wastes as a Heterogeneous Catalyst for Biodiesel Production. Sustainable Energy, 1, 7-13.

[31] Jazie, A.A., Pramanik, H. and Sinha, A.S. (2012) Eggshell Waste-Catalyzed Transesterification of Mustard Oil, Optimization Using Response Surface Methodology (RSM). International Conference on Power and Energy Systems (ICPES), Pune, 17-18 November 2012.

[32] Tangboriboon, N., Kunanuruksapong, R. and Sirivat, A. (2012) Meso-Porosity and Phase Transformation of Bird Eggshells via Pyrolysis. Journal of Ceramic Processing Research, 13, 413-419.

[33] Engin, B., Demirtas, H. and Eken, M. (2006) Temperature Effects on Eggshells Investigated by XRD, IR and ESR Techniques. Radiation Physics and Chemistry, 75, 268-277. https://doi.org/10.1016/j.radphyschem.2005.09.013

[34] Moradi, G.R., Mohadesi, M., Ghanbari, M., Moradi, M.J., Hosseini, S.H. and Davoodbeygi, Y. (2015) Kinetic Comparison of two Basic Heterogeneous Catalysts from Sustainable Resources for Transesterification of Waste Cooking Oil. Biofuel Research Journal, 6, 236-241. https://doi.org/10.18331/BRJ2015.2.2.5 